\title{
A Cognitive Linguistics Study of Ekegusii Onomastics: The Case of the Metaphor
}

\author{
Aunga Solomon Onchoke \\ Department of English and Linguistics, Southwest University, China
}

Copyright $\mathrm{C} 2018$ by authors, all rights reserved. Authors agree that this article remains permanently open access under the terms of the Creative Commons Attribution License 4.0 International License

\begin{abstract}
This paper will try to explore the motivation behind a cultural specific metaphor in Ekegusii onomastics as seen from a cognitive linguistics viewpoint. The study aims to identify and explain the Ekegusii names of people describe their social-cultural values and account for the cognitive processes involved in their interpretation. The data included a list of Ekegusii names collected from a primary school in the heartland of Gusii and discussed by an interview panel of natives combined with the researcher's knowledge, intuitions, experience, and introspection, then they were analyzed using the Cognitive Metaphor Theory of Lakoff and Johnson. The results suggest that interpretations and usage of personal names create mental images, have a meaning, and reflect the culture of the Abagusii people. Also, it is evident that metaphors pervade the lexicon of Ekegusii onomastics and form networks by which they conceptualize people's names in concrete terms as events, evil spirits, achievements, behavior, objects, places, animals, plants and special occurrences. The study concludes by suggesting further research into socio-cultural metaphors and metonymy in onomastics in African and other languages.
\end{abstract}

Keywords Metaphor, Cognitive Linguistics, Culture, Onomastics, Ekegusii

\section{Introduction}

This is a cognitive linguistics study of an African language, Ekegusii. It deals with onomastics (the study of the names of people). According to Guthrie [1], Ekegusii, whose speakers are called Abagusii, are labeled zone E42 narrow East African ${ }^{1}$ Bantu language group belonging to

1 Bantu - a group of people originally came from West Africa, in the interlacustrine zones, namely $\mathrm{D}$, and $\mathrm{E}$, occupying the Southern section of the western highlands of Kenya (Gusii land or Kisii). Their region is one of the most densely populated areas of Kenya, and the Gusii constitute the country's sixth largest ethnic group, comprising about seven percent of the national population [2]. The group has two dialects: Rogoro and Maate [3]. Just like in many African cultures, in birth and child naming among the Abagusii (as explained during the panel discussion by the natives), both male and female children are considered valuable and there is a clear division of labor between the sexes: males defend the community against invasion from the outside and ensure the continuity of the family and the clan; women bring livestock to enrich the family and clan through marriage, cook for the family and take care of the man and children. Women should give birth to as many children as possible because children were seen as a blessing. Women without children were ridiculed and shunned; barrenness was seen as a curse to the woman by the gods, thus, needed cleansing [4].

According to Akama and Maxon [5] and Monyenye [6], the culture of Abagusii exists before a child is born, a child has to live in it, and leave it behind after death. Women usually give birth to once every two or three years which is controlled by prolonged breastfeeding and men have several wives, so that when one wife has given birth, the man leaves her to live with the other wives. After a successful birth, there is a big ceremony to name the child and because a new member has been added to the family and clan. So, the experienced elderly women of the clan help the midwife to do the delivery. The husband is not allowed in the labor room, because of taboos or superstitions to ward off the bad spirits. Once the child is born there is merriment and a lot of eating to welcome the new member. Finally, the women who had assisted in the delivery process also help in getting the appropriate name

modern day Cameroon. The linguistic core of the Bantu family of languages, a branch of the Niger-Congo language family, was located in the adjoining region of Cameroon and Nigeria 
for the child. Men are locked out during the naming ceremony. There are many ways of choosing a name; these ways are what I call the source domains and the name is the target domain.

According to the discussants, during the naming exercise, the name of a recently deceased person of the same sex in the father's family is used for the first name, and a similar name from the mother's family for the second and less important name (these names also carry other meanings they symbolized before). As a totem, the Gusii avoid naming their children after dead unmarried people, cruel people, rapists, thieves, and other social misfits because it is believed that the child would turn out to be like the person they were named after. The boys are named after men and girls after women, but sometimes boys and girls carry similar names (unisex names can be used, depending on the occasion). Children are named after places and landmarks, animals, objects, plants, events or seasons, achievements and names are also given in order to chase away evil spirits. This is in line with other scholars in Africa who believe that a name is viewed as a message that the name-giver conveys to society through the bearer of that name. A name is like a book: one can read the history of the individual or the family in time and space [7]. People's names across numerous African ethnic groups have a meaning tagged to them; an African name defines an individual because it goes beyond an identity and is correlated to an infant's character as it grows up, and can either build or demean its reputation [8].

This paper is based on the premise that, from a cognitive point of view, names of people reflect cultural reality, people's attitudes, religion, philosophy, beliefs and world outlooks [9]. It is also based on the idea that "the roots of most of these names are culturally conditioned, since they stem from local geographical areas, plants, animals, local gods or specific and different languages" [10]. Chomsky [11] postulated that language can be viewed as a verbal expression of culture. Yet another scholar, Gleason [12] asserted that language and culture are closely related, and that language is used to express culture and cultural ties. The values, customs, and environment in the country we grow up in shape the way in which we think and behave [9]. In this study, we shall seek to establish how the Gusii culture influences the choice of names given to children. Ekegusii traditional names are examined; foreign names borrowed from neighboring communities or brought by religion and education are not included. It is worth noting that the Abagusii, just like other African cultures, have elaborated naming ceremonies [4]. First, we present a brief literature review of Conceptual Metaphor Theory and onomastics; then, the methodology used, findings, and a discussion will follow. An analysis of Ekegusii onomastics will then be undertaken.

\section{Brief Literature Review of Cognitive Linguistics, Conceptual Metaphors and Onomastics}

Cognitive linguists are concerned with discovering the way that language reflects people's perception of the world, that is, the processes of interpreting meaning and the mental concepts minds form and express about the world through language [13]. They argue that meaning does not exist independently from people that create and use it [14-19]. Researchers in the area agree that metaphors are a specific mental ${ }^{2}$ mapping that greatly influences the way people think, imagine and reason in everyday life. They believe in the principle that in human cognition, metaphors are at the center of speech production, communication, and processing of meaning which is dependent on mappings between domains [20].

Conceptual Metaphor Theory (CMT) was first posited by [14]. It was then developed and expounded by other cognitive linguistics researchers who argued that metaphors are a property of language, thought and a linguistic phenomenon, and that they involve perceiving one experience in terms of another [21, 22, 23, 24, 9, 25]. Thus, the metaphor always involves two concepts or conceptual domains: the target and the source. They argued further that according to CMT, we use imagination to map and understand experiences by either using metaphors or metonyms on the basis of image schemas with ontological correspondences between the domains: the target domain is abstract and understood in terms of the source domain because of sharing certain attributes [14, 26, 23, 25]. They noted further that linguistic metaphors are surface realizations of a deep system of conceptual metaphors. For instance, the conceptual metaphor, ARGUMENT IS WAR, is realized by the linguistic metaphor or expression, he attacked every weak point of my argument [14]. Here, an argument is perceived in terms of war. Three types of metaphors have been identified: ${ }^{3}$ structural, orientational and ontological $[14,27]$. The main tenets of the refined cognitive metaphor theory are ubiquity, domain, model, diachrony, unidirectionality, invariance, necessity, creativity, and focusing as summarized by ${ }^{4}[28]$.

\footnotetext{
2 Mapping is a process in which certain attributes of a metaphor vehicle are associated in a systematic way with (mapped onto) comparable attributes of the topic.

3 Structural metaphors establish mappings between elements belonging to structural conceptual domains, for instance, conceptualizing an argument in terms of war; ontological metaphors assign surfaces or boundaries to things that have no definite shape or form re-elaborating abstract entities in concrete terms, orientational metaphors are organized in terms of spartial orientation, and describe emotions and states of consciousness such as feelings, happy is up and sad is down, they take vertical or horizontal dimension[14, 26].

4 Jakel [28: 20-42] summarizes the 9 basic tenets of the Cognitive Theory of Metaphor as: ubiquity hypothesis, linguistic metaphor is ordinary everyday language; domain hypothesis, metaphorical expressions are linguistic realizations of conceptual metaphors; model hypothesis, conceptual metaphors form coherent cognitive models;
} 
Summarized the basic tenets of the refined Cognitive Theory of Metaphor in the form of nine hypotheses as discussed by early different cognitive linguists, it should be noted that not all of these will be used in the following study.

The importance of the metaphor in cognition has been a major puzzle to many linguists. Some scholars link it to the time of Aristotle as they try to understand its functions in language, cognition, and culture [21]. There has also been a great amount of debate concerning metaphor and culture from a cognitive point of view [29, 15]. Most theorists approaching metaphor from this viewpoint agree that there are cultural dimensions to the metaphor. Many other scholars in cognitive linguistics have stressed the importance of culture in conceptual metaphor theory discussions. Among them is Ritchie [30], who identified and described different types of metaphors, and asserted that many primary metaphorical concepts are based on culture-specific experiences. This position is in agreement with Lyons [31], who argued that the language of a particular society is an important part of its culture and that most words in a language demonstrate culturally important features of objects, institutions, customs, and activities in the society in which the language operates. Yet another scholar, Kevesces [9], questioned the universality of metaphors as suggested by Lakoff. He noted that the cultural context may override the universal mapping of metaphors. Consequently, Azuma [32] carried out research on how English native speakers interpreted Japanese culture-bound metaphors and concluded that the differences in culture affect the interpretations of the metaphor.

Different scholars in the field of cognitive linguistics have identified and discussed different types of metaphors, among them, are Lakoff and Johnson [14], and Grady [21,33] who distinguished different kinds of metaphors: primary (which have single meaning and linkage), complex (where literal meaning is expressed through more than one figurative term or a combination of primary metaphors or are multi-layered), linguistic (where expressions or words that come from the language or terminology of the more concrete conceptual domain(x-domain)), correlation (where different

diachrony hypothesis, Cognitive-semantic studies of metaphor show that even in the historical development of languages, most metaphorical meaning extensions are not a matter of isolated expressions; unidirectionality hypothesis, as a rule, metaphor (" $\mathrm{X}$ is $\mathrm{Y}$ ") links an abstract and complex target domain (X) as explanandum with a more concrete source domain (Y) as explanans, which is more simply structured and open to sensual experience; invariance hypothesis, in conceptual metaphors, certain schematic elements get mapped from the source domain onto the target domain without changing their basic structure; necessity hypothesis, metaphors have an explanatory function, creativity hypothesis, The potential meaningfulness of metaphor does not yield to simple paraphrase; its meaning cannot be reduced to a non-metaphorical, propositional format without loss, focusing hypothesis, metaphors only supply a partial description or explanation of the target domain in question, highlighting certain aspects while hiding others. experiences are cognitively correlated simultaneously), and resemblance metaphors (which have similarities between the source and target concepts whereby shared features of two different schemata are activated). Consequently, Takada et al. [34] used this resemblance metaphor which they called "social- cultural metaphors" in analyzing how a woman is perceived in Japanese.

Similarly, Maalej [35] analyzed conceptual metaphors in Tunisian Arabic and showed how they are influenced by cultural beliefs and practices. He discussed several expressions dealing with emotions like anger and how it is expressed differently using Tunisian Arabic culture-specific beliefs about physiology. He concluded that it is important to include cultural practices in any account of conceptual metaphors; this will be observed in the present study. Moore [36] agrees with the view that some conceptual metaphors are culture-specific and others are not.

Yet another scholar, in her research of nicknames of 43 American presidents used in political discourse, Gladkova [37], concluded that nicknames can provide insights into social relationships, culture, and language. Similarly, Dobric [10] carried out a research of onomastics in Serbian; he observed that although (as contemporary semantics recognizes) names do not have meaning, it was meaning that was essential in the primary origins of many personal names. He concluded that the roots of certain names seem to be highly culturally conditioned and that they stem from local geographical areas, local gods or specific and different languages. He proposed the use of metaphors as a more universal and basic principle of generating names and creating novel meanings. This study explores further resemblance metaphors [33, 34] and discusses the metaphor in Ekegusii onomastics, an African Bantu language from a cognitive linguistics point of view.

\section{Methodology}

The current study made use of a qualitative research design, in that it does not produce discrete numerical data $[38,39]$ and the researcher relied on the views of participants and analyzed the data in order to find themes [40]. This is a synchronic study because it describes the phenomena as they exist at a particular point in time without the intervention of an experiment or artificially contrived treatment and the researcher relies on the views of the respondents and analyses words for themes [39, 41]. The researcher got names from Ikonge primary school in Nyamira County which is in the heartland of Gusii land. It is a rural school with 450 pupils. Each class is comprised of 50 pupils and classes range from pre-school level to standard eight. We selected 400 names with salient features (Ekegusii names only) from the school nominal roll as given by the head teacher. The researcher then 
discussed the names with a panel of 10 elderly people of between 50 and 70 years of age ( 5 men and 5 women) proficient in the native language, born and brought up in Kisii. They were chosen from the many using judgmental sampling technique. This small sample was chosen in order to allow for in-depth investigation and analysis of data [42].

The researcher, assisted by the research assistant, asked the panel questions about the names collected as he captured their explanations assisted by a video camera. In addition, the researcher asked them to describe the origins and the cognitive processes associated with the personal names and to further explain the literal and implied meanings that some of these processes elicited. They were further asked to name the contexts in which these names were given. The panel discussion permitted a greater depth of response which in turn gave an insight into the feelings, backgrounds, hidden motivations, intuitions, interests and decisions of the panelists about their culture [39]. This study, therefore, utilized data in the form of words and phrases in order to obtain detailed information about how names are given to children and their meanings. Then the researcher proceeded to establish patterns, trends, and relationships from the gathered information.

The data obtained was presented in Ekegusii orthography and a gloss in English was then provided. The recorded data was transcribed, translated and coded. A list of 100 names was picked which had salient features. The data was checked to make sure that it contained only the required attributes, then sorted out and classified into different categories by looking at the values that were related. A list of these categories was then compiled and patterns emerged. Similarly, the images that the names implied to were explained and the researcher proceeded to show how these names were interpreted in the Gusii society. The social-cultural values from the data on the cognitive processes were then mapped from the $\mathrm{X}$ to the $\mathrm{Y}$ domains and analyzed using CMT.

\section{Results and Discussion}

In this section, the data collected from the field is presented and discussed to show how the Abagusii conceptualize names given to people. The names were classified into male, female and unisex (given to both men and women) names by the researcher and the panel. Tables and pie charts were used to aid the presentation. The figure that follows gives a summary of the names in Ekegusii as collected (for a complete list of names, see the appendix).

\section{Percentage of names of people in Gusii}

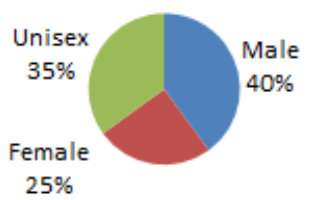

Figure 1. Summary of names of people in Ekegusii

Figure 1 shows that a total of 100 names in Ekegusii were collected from the respondents. The names were then classified as male, female and unisex (Given to either male or female). There were 40 names for male, 35 for unisex and 25 female, representing $40 \%, 35 \%$, and $25 \%$ respectively. When the panel of native discussants was asked why the males attracted more names than the females, the majority of them agreed that it is because the community is male chauvinistic and patriarchal.

According to Zawawi [42], personal names provide an important component of African cultural identities and play psychological roles in establishing a person's identity. Names also convey, to those who know their origin and meaning, the social and cultural experiences of the people who have created them. Zawawi further added that names depict how members of a community regard themselves because they reflect values, traditions, and events in people's lives. It is also good to observe that languages like Ekegusii provide its speakers with an adequate system for making any kinds of observations about their surroundings and the world in general [44]. Names are therefore meaningful words containing historical, social, geographical and philosophical contexts. This explains why children's names are chosen with much consideration even among the Abagusii. The same sentiments are echoed by Mutunda [7] when he argues that unlike in Europe, where a name has no meaning, in Africa names are viewed as a message that a name giver conveys to a society. In Ekegusii onomastics, these names to a native speaker, invoke mental images and meanings, therefore, they are metaphorical.

Metaphors convey the images, feelings, values, religious beliefs, philosophy, customs and thought patterns in our cultures [45]. There are different cognitive processes involved in the mapping and interpretation of the Ekegusii names from the source and target domains; different ways of naming children and names, which are, in this case, the source and target domains respectively. This is stressed by Kovecses [9] when he says that a metaphor is based on similarity and cross-domain correlations in our experience, which give rise to the perceived similarities between the two domains within the metaphor. 


\section{The Mapping Processes}

According to Brozoviæ-Ronèeviæ \& Zic-Fuchs [46], names carry meaning in their original form from the point of their creation and meaning lies behind the motivation for their first usage in denoting a human being. The current study used a social- cultural metaphor model in which interpretations of the metaphors depend on the social-cultural settings of where the metaphors are taken from, whereby the source and target domains are defined by similar properties during the mapping [19, 34].The way the Abagusii community understands and conceptualizes a name was investigated. The different ways of naming a child (also the properties involved in mapping), in this model, will act as the $\mathrm{X}$ domain and the name is the $\mathrm{Y}$ domain. This model fits in this study because specific qualities of the source (events, evil spirits, achievements, behaviors, objects, places, animals, plants and special occurrences) as understood and perceived in Ekegusii culture, are mapped onto the target (people). The discussion that follows gives a summary of how the Abagusii conceptualize names of people and the mapping from the $\mathrm{X}$ to the $\mathrm{Y}$ domains. The table below gives a summary of the major areas of conceptualization.

Table 1 below gives a summary of the areas mapped, the number of names in each category $(\mathrm{M}=$ male, $\mathrm{F}=$ female, and $U=$ unisex) and the percentages of each category. There were more names for males than for females and those shared by both. The reason could be because the Abagusii are a patriarchal society (male dominance), that is, men are more valued and look down upon women. Akama \& Maxon [5] explain that when children are born into the Gusii community, their lives are already predetermined by existing social forces. This is due to the fact that a child is born into an already existing distinct cultural system. The community believes in supernatural forces that control even the names given to children. Using CMT from Lakoff and Johnson [14], the following broad areas of conceptualization or themes were identified as shown from the table: place with $17 \%$ of the names collected, followed by events and seasons at $16 \%$, animals and evil spirits at $12 \%$, special occurrences $11 \%$, behaviors and achievements at $9 \%$, objects $8 \%$ and lastly, plants at $6 \%$ of the names collected. It is of paramount importance to stress that a study of this kind requires the understanding of social and cultural backgrounds to discover various relationships and social codes that motivate the metaphors. Next, we discuss the areas mapped with a few examples of Ekegusii personal names to illustrate the correspondences.

Table 1. Summary of areas mapped, sex and percentages of names of people in Ekegusii

\begin{tabular}{|c|c|c|c|c|c|c|c|c|c|c|}
\hline \multicolumn{2}{|c|}{ Areas } & $\begin{array}{c}\text { Surrounding } \\
\text { place }\end{array}$ & Events \& Seasons & $\begin{array}{c}\text { Evil Spirits/gods/ } \\
\text { Reincarnations }\end{array}$ & Behaviors & $\begin{array}{c}\text { Achievements/ } \\
\text { Professions }\end{array}$ & Objects & Plants & Animals & $\begin{array}{c}\text { Special } \\
\text { occurrences }\end{array}$ \\
\hline S & $\mathrm{M}$ & 12 & 10 & 7 & 7 & 6 & 6 & 6 & 10 & 3 \\
$\mathrm{E}$ & $\mathrm{F}$ & 4 & 4 & 1 & - & - & 1 & 1 & - & 2 \\
$\mathrm{n}$ & $\mathrm{U}$ & 1 & 2 & 4 & 2 & 2 & 1 & 1 & 2 & 6 \\
\hline \multicolumn{2}{|c|}{$\%$} & 17 & 16 & 12 & 9 & 9 & 8 & 6 & 12 & 11 \\
\hline
\end{tabular}




\section{a. A PERSON IS SURROUNDING OR PLACE}

Ontological Correspondence

\begin{tabular}{rr}
\multicolumn{2}{c}{ Ontological Correspondence } \\
Source Domain & Target Domain \\
Surrounding or place & $\longrightarrow$ Name of a person
\end{tabular}

It is argued that place names are an important part of our geographical and cultural environment, and that they identify localities of different kinds and represent irreplaceable cultural values of vital significance to people's sense of belonging and well-being [47]. According to Guthrie [1], the Bantu people originally came from West Africa, in modern day Cameroon and entered into Kenya through the North, and split up into different groups with the Kisii ending up in Nyanza Province near Lake Victoria. During their migration, they encountered several landmarks and since language reflects a people's culture and history [31], their naming reflects the significant landmarks which they encountered during their migration to the current place of settlement like roadsides, beside a river, paths traveled, hills, jungle, by a pond or under a tree. The entities being mapped here are the nature of the places and the time of the event. As seen from the table, this group had the largest number of names. Names like Nyanchera (born along the roadside), Makori (born along a footpath), Matoke (born inside a banana plantation), Ogwagwa (born near herbs), Rosana (born near the forest), Kwamboka (crossing a bridge), Kemunto (rounding a gulf or anthill), Kerubo (wandering on a plain), Nyaboke (born in an area with a lot of honey), and Moraa (born in a jungle where there are herbs called emeraa), were, and still are, often used extensively among the Gusii people. These names remind the community members and draw pictures of the listeners to their habitats and landmarks and also places they passed in the course of their migration, hence forming part of their linguistic repertoire and history. Therefore, place names are linked to past events and are pegs upon which stories both written and oral can be hung as synchronic and diachronic expressions attached to smaller or bigger places; place names are a vital part of everyday language as well as of the individual and collective memory and collective identity [48].

\section{b. A PERSON IS AN ANIMAL}

Ontological Correspondence

$\begin{array}{rr}\text { Source Domain } & \text { Target Domain } \\ \text { Animal } & \longrightarrow \quad \text { Name of a person }\end{array}$

Kövecses [9] notes that people use animals to depict humans because the behaviors of these animals are often overt. Depending with the type of animal, the behaviors could be positive or negative. Similarly, Lawrence [49] \& Shepard [50] argue that humans have used animal characters in metaphoric expressions for ages because animals convey different feelings, thoughts, and fantasies which objectify human qualities and traits. This type of metaphor has the basic level of mapping and several other lower levels or layers of schematic mapping depending on the particular animal. According to Lakoff and Johnson [14], A PERSON IS AN ANIMAL, is the basic metaphor where an animal is perceived as a person. The qualities mapped are the sizes of the animals and their perceived behaviors as understood from folk tales. Many people from this society share names with animals. It is common to encounter names such as Kerongo, Mbeche and Gekondo (this is a porcupine, warthog and a monkey respectively; such a child was seen as very ugly when given birth to, thus, BEING UGLY IS BEING A PORCUPINE or WARTHOG or A MONKEY, Onchoke (a bee; such a child cried a lot immediately after birth signifying harshness, thus, BEING HARSH IS BEING A BEE), Nyangau (hyena; a child who breast feeds a lot, thus, BEING GREEDY IS BEING AN HYENA). Onyambu (Chameleon; a very slow child, thus, BEING SLOW IS BEING A CHAMELEON), Machogu (elephant; a child born big, thus, BEING BIG IS BEING AN ELEPHANT), Basweti (python; a pretentious child, thus, BEING A HYPOCRITE IS BEING A PYTHON), Masimba (lion; born brave, thus, BEING BRAVE IS BEING A LION) and Ongondi (sheep; born with the perception that child is stupid, therefore, BEING STUPID IS BEING A SHEEP).

\section{c. A PERSON IS AN EVENT OR SEASON}

$$
\text { Ontological Correspondence }
$$

Source Domain

Target Domain

Event or season

Name of a person

Before the introduction of formal education in Africa by the Europeans, Africans had their own ways of remembering important seasons and events [9]. One way of keeping an event fresh in people's memory was through naming. People are conceptualized as events or seasons depending on when they were born. This group has the second largest number of names of people as seen from the data collected. Names such as Momanyi (born during war with the neighboring tribes), Ongige (born during the time of movement of locusts), Nyangweso (born during hunger), Mirigi (born when a certain joint disease attacked people), Bosibori (a girl born during a wedding ceremony), Ouru (a baby boy born during Kenya's independence), Mosigisa (a child born during the harvesting of millet), Kerebi (a girl born when head scarves for women were introduced by foreigners), Motuka or Orori (born when cars arrived in Gusii land), Sigara (born when cigarettes were introduced) and Aunga (when maize floor was introduced in Gusii land). These names not only served to remind the community of the important events, but also, their historical calendar. 


\section{d. A PERSON IS AN OBJECT}

\section{Ontological Correspondence}

Source Domain
Object

Target Domain

$\longrightarrow$ Name of a person

People use machines and tools or objects to work, play, fight, and for pleasure; these things and the activities related to them show up as metaphorical expressions [28]. This metaphor can operate at the basic level of mapping (A PERSON IS AN OBJECT), and also at other several lower levels of schematic mapping depending on the object. Some names given to children imply certain objects. Names such as Nyangena or Magena (the grinding stones to remind the child of the importance of the stone for grinding millet and a place of birth; also such a child is perceived as hardy and unfeeling like a stone; BEING HARDY IS BEING A STONE), Rioba (the mother saw the returning sun before delivery), Bisieri (door; name meant to close doors of death in case other children had been dying in the family; such a child was also perceived to be generous; BEING GENEROUS IS BEING A DOOR), Ondari (wedge; the head was shaped like a wedge when born, such a child was perceived to be sharp; BEING WISE IS BENG A WEDGE), Bitange (railway; a child born on a train) and Tai (tie; born looking beautiful or handsome; BEING SMART IS WEARING A TIE).

\section{e. A PERSON IS A SPIRIT OR REINCARNATE NAME}

\section{Ontological Correspondence}

\section{Source Domain}

Good/bad spirit

\section{Target Domain \\ Name of a person}

A person is conceptualized as an evil or good spirit depending on the circumstances the child was born. A child was given a name to chase away an evil spirit or bad omen. For example, if a mother had been losing babies at childbirth, she would decide to take her new child and leave it at a public place for travelers to bless it in order that it might live. Such public places included the roadside, beside a river, by a pond or under a tree. This was taking a big risk since a hyena could eat it or a snake could bite it. Names like Onsure (born after a sister or the death of a sister, bringing a good omen to the mother to give birth to other children), Masese (meant to confuse evil spirits when there are misfortunes in the family), Nyandege (Given to a child so as to curse evil spirits which could harm the young ones), Bonareri (given to a girl child to send evil spells away) Mabera (mercy; meant to appease evil spirits) and Bogomba (the child is the first child the mother has given birth to in a while, encouraging the womb to deliver more children to the mother). These names, apart from being symbolic, were meant to chase away evil spirits and protect the bearers.

\section{f. A PERSON IS A PLANT}

$$
\text { Ontological Correspondence }
$$

Source Domain Target Domain

Plant $\longrightarrow$ Name of a person

People have always found similarities between plants and human beings. Plants provide our basic needs in shelter, food, medicines and clothing. Lakoff and Turner [51:172] posit that the Great Chain of Being Metaphor allows us to comprehend general human character traits in terms of well-understood nonhuman attributes such as plants, giving the A HUMAN IS BEING A PLANT conceptual metaphor. Similarly, Kövecses [24] explored how plants can be conceptualized as abstract things, social organizations, scientific disciplines, people, economic and political systems, human relationships, sets of ideas etc., thus, the giving the conceptual metaphor, COMPLEX ABSTRACT SYSTEMS ARE PLANTS. In this study, the conceptualization of people as plants is not pejorative but positive. In this community, common names identified are Masereti (child born where there is star grass), Matoke (given to a child if the first woman to see the child brought the mother bananas or the child is born in a banana plantation), Ogwagwa (born where there are traditional herbs), Nyasuguta (girl born where there is grass), Nyamoko (born near a tree called Omoko) and Rosana (born in the forest). These names portrayed the picture of the culture of the Abagusii and their environment.

\section{g. A PERSON IS AN ACHIEVEMENT OR PROFESSION}

$$
\begin{array}{cl}
\multicolumn{2}{c}{\text { Ontological Correspondence }} \\
\text { Source Domain } & \text { Target Domain } \\
\text { Achievement or profession } \longrightarrow & \text { Name of a person }
\end{array}
$$

These were names that were acquired during one's lifetime based on personal praises, occupation, attire, peculiar utterances, mannerisms, etc. An example is Mogambi or Ogamba, which means a leader, Nyarangi means painter, Omete is a medicine man, Gechemba is a rainmaker and Morani meaning a warrior. These names give a picture of the community's professions and culture before the coming of the Europeans. These names also tell a lot about the individual; they signify the language and society from which they are drawn [52].

\section{h. A PERSON IS BEHAVIOR}

$$
\text { Ontological Correspondence }
$$


Cisek [53] describes behavior as a control process where actions are performed in order to affect perceptions. After a child has been given a family name, women can observe the child and give it a name according to the character it exhibits as it grows. Children born within a few minutes of the onset of labor pains, were interpreted by a midwife and the helpers as quick, steady, clever and wise, they will be called Mwango, a unisex name. A male child that is born and does not cry a lot and smiles at is called Omwancha, meaning love. Mosoku was a shy child when young and Onyonka was a very sensitive child in identifying family members and friendly people when held. Nyachae was a name given to male children that evoked images of generosity among the community members and Nyariki was a name given to a child seen to be intelligent and hard working. A close analysis of these names show the salient character traits that the society wished its members to portray.

\section{i. A PERSON IS A SPECIAL OCCURRENCE}

$$
\text { Ontological Correspondence }
$$

\section{Source Domain}

Special occurrence
Target Domain

Name of a person
These were names given to children based on the relationships, the body structure of a child or the position in the family. The first born child was named Motangi, and the last born, Mokogoti. Twins had special names; a boy was named Moirongo and a girl, Barongo (sometimes both could share the name Barongo), a child that was born after the twins was named Chacha. A baby boy born after a couple hadn't had a child in a while was referred to as Mogaka and a baby girl, Mongina which meant special love for the father and mother. A child born with a diminutive body structure was named Ogake and one with a big body structure was named Monene. These names give a picture of the community's culture. Thus, when one encounters an Ekegusii name of a person, he or she should think about the hidden meaning.

\section{Conclusions}

In this study, we have explored resemblance metaphors using the socio-cultural model $[19,34]$. It is evident that metaphors pervade the lexicon of Ekegusii onomastics and form linkages by which we conceptualize people's names in concrete terms, that is, PEOPLE ARE EVENTS, PEOPLE ARE EVIL SPIRITS, PEOPLE ARE ACHIEVEMENTS, PEOPLE ARE THEIR BEHAVIOR, PEOPLE ARE OBJECTS, PEOPLE ARE PLACES, PEOPLE ARE ANIMALS, PEOPLE ARE PLANTS and PEOPLE ARE SPECIAL OCCURRENCES. Some of these metaphors have also underlying lower layers of schematic mapping.

The study has also established that Abagusii being a male chauvinist society, the males were seen as better and more important, therefore, attracted more names than the female counterparts. In addition, metaphors depend on socio-cultural settings, and cognition is deeply related to our understanding of society and culture; therefore, the cultural specificity of personal names in Ekegusii should be appreciated. We can also discern that names of people among the Abagusii are metaphorical which appeals directly to the senses of listeners or readers, sharpening their imaginations to comprehend what is being communicated to them. Moreover, metaphors give a life-like quality to our conversations, and are also ways of thinking, offering listeners and readers' fresh ways of examining ideas and viewing the world. Also, we can conclude that conceptual metaphors structure and restructure the physical world through the names of people.

Finally, we suggest that more studies about socio-cultural metaphors and metonymy should be undertaken of other languages to enable comparative studies in onomastics and cognitive linguistics. 


\section{Appendix}

\begin{tabular}{|c|c|c|c|}
\hline 1. & Kemunto- Jumping over an anthill(F) & 51. & Onchoke-bees(M) \\
\hline 2. & Nyanchera or Onchera- born along the roadside(U) & 52. & Kerebi- born when head scarves were introduced(F) \\
\hline 3. & Makori- born along a footpath(m) & 53. & Motuka- born when motor vehicles came to kisii (M) \\
\hline 4. & Momanyi-born during war(m) & 54. & Gechure-antelope(M) \\
\hline 5. & Obaga- sending away evil spirits(m) & 55. & Mabera- born to appease evil spirits(M) \\
\hline 6. & Ongombe- born inside a cattle shed(m) & 56. & Sigara- born when cigarettes were introduced(F) \\
\hline 7. & Kwamboka- when mother was crossing the bridge(f) & 57. & Kerongo-Porcupine (M) \\
\hline 8. & Ongige- born during the time of locusts(m) & 58. & Bochaberi-born inside trees $(\mathrm{F})$ \\
\hline 10. & Onsure- born after a sibling had died(M) & 60. & Bisieri born after others had died(F) \\
\hline 11. & Kerubo- born on plains(f) & 61. & Ouru-born during independence struggle(M) \\
\hline 12. & Nyariki- hard working boy & 62. & Omwancha- loves people(M) \\
\hline 13. & Moraa- born inside trees(f) & 63. & Omariba-where there is clay(M) \\
\hline 14. & Michira-living at a new place(m) & 64. & Nyatera-survived evil spirits(U) \\
\hline 15. & Basweti- mother saw a python before delivery $(\mathrm{m})$ & 65. & Nyachae- tea symbolize generosity(M) \\
\hline 16. & Rioba-Born when the mother saw a setting $\operatorname{sun}(\mathrm{m})$ & 66. & Omuga-confident(M) \\
\hline 18. & Nyanchoka- Mother saw a cobra before delivery(U) & 68. & Mongina- mother(F) \\
\hline 19. & Masereti- born where there is star grass(M) & 69. & Onyambu-chameleon(M) \\
\hline 20. & Matoke- born on a banana plantation(U) & 70. & Atera-appease the gods(M) \\
\hline 21. & Nyabando-born when maize was introduced(M) & 71. & Machogu-elephant(M) \\
\hline 22. & Getuma-born at a fence (M) & 72. & Masimba or samba- lion(M) \\
\hline 23. & Nyangena- Grinding stone(U) & 73. & Guto- hedgehog(M) \\
\hline 24. & Moturi-blacksmith(M) & 74. & Orori- vehicle (M) \\
\hline 25. & Masese-Name given to confuse evil spirits(U) & 75. & Ogamba- leader(M) \\
\hline 26. & Nyambaria-born where there are goats(U) & 76. & Aunga- born when maize floor was introduced(M) \\
\hline 27. & Ongondi-Sheep(M) & 77. & Onyonka- sniffy(M) \\
\hline 28. & Mbori-sheep(M) & 78. & Ombura - rain $(\mathrm{M})$ \\
\hline 29. & Nyandege- Given to curse the spirit which harms the young ones(U) & 79. & Mwango- wise, clever, quick(M) \\
\hline 30. & Nyarangi-painter(M) & 80. & Mosoku-shy(M) \\
\hline 31. & Nyasuguta-grass(F) & 81. & Motangi- firstborn (U) \\
\hline 32. & Bosibori-born during wedding $(\mathrm{F})$ & 82. & Mokogoti-last born(U) \\
\hline 35. & Manyega- weak or sagging(M) & 85. & Chacha-follower of twins(U) \\
\hline 36. & Nyamache-born near water(M) & 86. & Okwanyo-thief(M) \\
\hline 37. & Obonyo- near locusts $(\mathrm{U})$ & 87. & Mogaka-father(M) \\
\hline 38. & Agwata- send away evil spirits(M) & 88. & Mogambi or Ogamba- leader(M) \\
\hline 39. & Mogondo- Orphan born on a farm(U) & 89. & Mbeche- warthog(M) \\
\hline 40. & Nyaboke-wedding name(F) & 90. & Nyangau-hyna(M) \\
\hline 41. & Onchwani-taken to the roadside to chase away evil spirits(M) & 91. & Nyakerario-born in an animal shed(F) \\
\hline 42. & Kegoro-born on a hill(M) & 92. & Nyabiagiro- hard working(F) \\
\hline 43. & Manani- Appease evil spirits(M) & 93. & Ogeti-playing field(M) \\
\hline 44. & Gechemba-rainmaker(U) & 94. & Nyabiage- store(M) \\
\hline 45. & Omete- medicine man(M) & 95. & Kerandi-mild guard(M) \\
\hline 46. & Ogwagwa-herbs(M) & 96. & Onkoba- thunder(M) \\
\hline 47. & Mosiabano-born accidentally(M) & 97. & Nyagucha- a big river(U) \\
\hline 48. & Rosana- forest(M) & 98. & Gekondo or bikundo- monkey(M) \\
\hline 49. & Bogomba- born after mother staying long without a child(U) & 99. & Ongera- buffalo(M) \\
\hline 50. & Nyaanga-born when clothes were introduced(U) & 100. & Geticha- born in a vegetable garden $(\mathrm{F})$ \\
\hline
\end{tabular}

[4] N. Thomas. "Detachable Women: Gender and Kinship in Process of Socioeconomic Change among the Gusii of Kenya." American ethnologist, 21:516-538, 1994

\section{REFERENCES}

[1] M. Guthrie. The classification of Bantu languages. London: Dawnson's Pall Mall Publishers, 1964.

[2] Government of Kenya. The national population and housing census. Nairobi: Government press, 1999.

[3] F. Bosire. "Dialects Rogoro and Maate" University of Nairobi Unpublished MA Thesis, 1993.
[5] J. Akama, \& R. Maxon. Ethnography of the Gusii of Western Kenya: A vanishing cultural heritage. New York: The Edwin Mellen Press, 2006.

[6] S. Monyenye. Rites of passage: Ceremonies for cultural identities among some Kenyan societies: The case of Abagusii community of South Western Kenya. Nairobi. University of Nairobi, 2004.

[7] S. Mutunda. Personal Names in Lunda Cultural Milleu. In 
International Journal of innovative interdisciplinary research. USA: University of Arizona, 2011.

[8] E. Ombui. Meaning of African people's names. African language technology. Nairobi: University of Nairobi, 2007. guy@aflat.org

[9] Z. Kövecses. Metaphor in culture: Universality and variation. Cambridge, MA/New York: Cambridge University Press, 2005.

[10] N. Dobric. 'Theory of names and cognitive linguistics-The case of the Metaphor' Germany. University of Klagenfurt Unpublished PhD Thesis, 2010.

[11] N. Chomsky. Language and mind. Enlarged ed. New York, MIT: Harcourt Brace Jovanovich, Inc. 1972

[12] S. Coulson. Electrifying results: ERP data and cognitive linguistics. In M. Gonzalez-Marquez, I. Mittelberg, S. Coulson \& M. J. Spivey (eds.) Methods in cognitive linguistics. Amsterdam: John Benjamins, 400-423, 2007.

[13] B. Dancygier \& E. Sweetser. Figurative language. Cambridge: CUP, 2014.

[14] G. Lakoff, \& M. Johnson. Metaphors We Live By. Chicago and London: The University of Chicago Press, completed with an Afterword in 2003, 1980.

[15] G. Lakoff. Contemporary Theory of Metaphor. In Ortony, A (ed.) Metaphor and thought. Cambridge: Cambridge University press, 1993.

[16] G. Lakoff, \& M. Johnson. Philosophy in the flesh: The embodied mind and its challenge to Western thought. New York: Basic Books, 1999.

[17] C. Fillmore. "On the organization of Semantic Information in the Lexicon", in D. Farkaset et al (eds.). Papers from the parasessonon the lexicon. Chicago: Chicago Linguistic Society, pp. 148-173, 1978 .

[18] A. Wierzbicka. Emotions across languages and cultures: Diversity and universals, Cambridge University Press, Cambridge, UK, 1999.

[19] J. Grady. "A typology of motivation for conceptual metaphor: correlation vs. resemblance," in R. Gibbs and G. Steen (eds.), Metaphor in cognitive linguistics, John Benjamins, pp. 79-100, 1999.

[20] G. Fauconnier. Mappings in thought and language. Cambridge, England: Cambridge University Press, 1997.

[21] R. Gibbs. W. The poetics of mind. Cambridge: Cambridge University Press, 1994.

[22] J. Grady. "Theories are buildings revisited," Cognitive linguistics, 8-4, pp. 267-290, 1997.

[23] R. Langacker. Grammar and conceptualization. Berlin-New York: Mouton de Gruyter, 1999.

[24] Z. Kövecses. Metaphor: A practical introduction. Cambridge: CUP, 2002.

[25] V. Evans \& M. Green. Cognitive linguistics. An introduction. Edinburgh: University Press 2006.

[26] G. Lakoff. Women, fire, and dangerous things: What categories reveal about the mind. Chicago: University of
Chicago Press, 1987.

[27] Z. Kövecses. Metaphor: A practical introduction. Oxford: Oxford University Press, 2010.

[28] O. Jäkel. Hypotheses revisited: The cognitive theory of metaphor applied to religious texts. Metaphorik.de, 2(1), 20-42, 2002.

[29] M. Johnson. The body in. the mind: The bodily basis of meaning, imagination, and reason. Chicago: University of Chicago Press, 1987.

[30] D. Ritchie. Metaphor. New York: Cambridge University Press, 2013.

[31] R. Lyons, J. Introduction to theoretical linguistics. New York: Cambridge University Press, 1968

[32] M. Azuma. English Native Speakers' Interpretation of Culture-Bound Japanese Figurative Language. In MacArther $\mathrm{F}$, et al. (eds). Metaphor in use: Context, Culture and communication. Amsterdam/Philadelphia: John Benjamin's Vol. 38 pgs. 50-80, 2012.

[33] J. Grady. Primary metaphors as inputs to conceptual integration. Journal of pragmatics, 37, 1595-1614, 2005.

[34] M. Takada, et al. A Study of Metaphorical Mapping Involving Socio-Cultural Values: How woman is conceptualized in Japanese. In Husby G, Sletton K. \& Michaelson (eds) Scandinavian Journal of immunology: Scandanavia. Vol 2 Pp. 394-404, 2006.

[35] Z. Maalej. Figurative language in anger expressions in Tunisian Arabic: An extended view of embodiment. Metaphor and symbol, 19, 51-75, 2004.

[36] K. Moore. Space-to-time mappings and temporal concepts. Cognitive linguistics, 17, 199-244, 2006.

[37] A. Gladkova. The Semantics of nicknames of the American presidents. Australia: Australian National University, 1999.

[38] O. Mugenda, and A Mugenda. Research methods: Quantitative and. qualitative Approaches. Nairobi: Act press, 1999.

[39] B. Zielinski W. The listener: No longer the silent partner in intelligibility. System, 36(1), 69- 84, 2008.

[40] M. Patton Q. Qualitative research and evaluation methods. Thousand Oaks, CA: Sage Publications, 2002

[41] H. Seligar and E. Shahomy. Second language research methods. Oxford University press, 1989

[42] P. Trudgill. Applied Sociolinguistics. London: Academic Press, 1973.

[43] S. Zawawi, M. African Muslim Names: Images and identities. Trenton, NJ: Africa World Press, 1998.

[44] R. Anderson, S. Remarks on the phonology of English inflection." Language \& literature, I (4):33-52, 1973.

[45] S. Coulson. Electrifying results: ERP data and cognitive linguistics. In M. Gonzalez-Marquez, I. Mittelberg, S. Coulson \& M. J. Spivey (eds.). Methods in cognitive linguistics. Amsterdam: John Benjamins, 400-423, 2007.

[46] Brozoviæ Ronèeviæ, Dunja i Zic Fuchs, Milena. Metafora I 
metonimija kao poticaj u procesu imenovanja", Folia onomastica croatica 12 (1), 91-104, 2003-2004.

[47] K. Zilliacus. Ortnamnsvård och ortnamnsplanering. Handlingar från NORNA: $\mathrm{s}$ femte symposium på Hanaholmen, (ed.). 23-25.9.1977 [Place name care and place name planning. Proceedings from NORNA's Fifth Symposium in Hanaholmen 23-25. 9. 1977]. NORNA-rapporter 13, 1978.

[48] T. Eskeland. Stedsnavn og identitet [Place names and identity]. Nordlit 10, 2001. http://www.hum.uit.no/ nordlit/10/1eskeland.html.

[49] E. Lawrence. The sacred bee, the filthy pig, and bat out of hell. Animal symbolism as cognitive biophilla. In The Biophilla Hypotheses, 301-340, ed. S. Kellert and E. O
Wilson. Washington DC: Island Press, 1993..

[50] P. Shepard. The Others: How animals made us human. Washington DC: Island Press, 1996.

[51] G. Lakoff and M. Turner. More than cool reason: A field guide to poetic metaphor. Chicago: The University of Chicago Press, 1989.

[52] M. Lupenga. Naming and Linguistic Africanisms in African American Culture. Edited by. J, Mugane, P. John, Hutchison and A. Dee.. Selected Proceedings of the 35th Annual Conference of African Linguistics. Somerville, MA: Cascadilla Proceedings Project, 2006.

[53] P. Cisek. Beyond the computer metaphor: Behavior as interaction. Journal of consciousness studies, 6(11), 125-42, 1999. 